\title{
Pengetahuan, Sikap dan Keterampilan Guru Sebagai Prevensi terhadap Kekerasan Seksual Pada Anak
}

\author{
Oleh: \\ Mentari Marwa \\ (Program Studi Psikologi Islam Institut Agama Islam Tribakti Kediri)
}

\begin{abstract}
Abstrak
Tulisan ini bertujuan menguji pemberian Pelatihan perlindungan anak pada Guru SD sebagai prevensi primer kekerasan seksual pada anak untuk peningkatan pengetahuan, sikap dan keterampilan menyampaikan informasi di Tulungagung Jawa Timur. Metode penelitian menggunakan untreated control group design with pre-test and post-test. Terdapat 21 guru SD yang terlibat dalam penelitian. Instrument yang digunakan adalah kuesioner, observasi. Uji mann whitney u-test untuk menguji perbedaan gain score kelompok eksperimen dan kelompok kontrol. Hasil penelitian menunjukkan ada pengaruh signifikan pemberian program perlindungan anak terhadap KSA oleh Guru terhadap peningkatan pengetahuan, sikap, dan ketrampilan guru sebagai prevensi primer kekerasan seksual pada anak SD di Tulungagung Jawa Timur, yang ditunjukkan dengan hasil mann whitney dengan $p$ value di bawah taraf signifikan 0,05 ( $p<0,05)$.
\end{abstract}

Kata kunci: $\quad$ kekerasan seksual pada anak, prevensi primer. Abstract

This paper aims to examine the provision of child protection training at the elementary school teachers as primary prevention of child sexual abuse to increase knowledge, attitudes and skills to convey information in Tulungagung, East Java. The research method using untreated control group design with pre-test and posttest. There are 21 elementary school teachers who are involved in the research. The instrument used was a questionnaire, observation. Test Mann Whitney U-test 
to test for differences in gain score the experimental group and the control group. The results showed no significant effect giving child protection programs against KSA by Guru to the increase of knowledge, attitudes, and skills of teachers as primary prevention of sexual assault at elementary school children in Tulungagung, East Java, as indicated by the results of Mann Whitney $p$ value below a significant level 0,05 ( $p$ $<0.05)$.

Keywords: sexual assault on a child, primary prevention.

\section{Pendahuluan}

Pada tahun 2009, Pusat Data dan Informasi Nasional mencatat kekerasan terhadap anak yang dilaporkan ke Komisi Nasional Perlindungan Anak sebanyak 1.552 kasus kekerasan terhadap anak yang terdiri dari kekerasan fisik 456 kasus, kekerasan seksual 557 kasus, kekerasan psikis 539 kasus; sedangkan pada tahun 2010 meningkat menjadi 2.413 kasus yang terdiri dari Kekerasan fisik 646 kasus, kekerasan seksual 926 kasus, kekerasan psikis 841 kasus (Samsudin, 2009). Berdasarkan data penanganan kasus dari Lembaga Perlindungan Anak (LPA) bersama UPPA Polres Tulung Agung tahun 2012 - 2013 dari 108 kasus yang ditangani terdapat 83 kasus kekerasan seksual pada anak (KSA), 7 kasus kekerasan fisik, 11 kasus penelantaran, 7 kasus emosional dan eksploitasi. Hal ini juga disampaikan oleh ketua LPA Tulung Agung, bahwa kasus KSA di LPA Tulung Agung lebih tinggi jika dibandingkan dengan Kediri dan Blitar yang merupakan satu karisidenan. Satu hal yang memprihatinkan, berdasarkan data dari berbagai daerah dan hasil penelitian, pelaku kekerasan seksual pada anak adalah orang-orang yang telah dikenal baik dan memiliki hubungan dekat dengan anak (Barron \& Topping, 2010 b).

Anak-anak merupakan kelompok yang sangat rawan terhadap tindakan kekerasan, seperti penganiayaan, pelecehan bahkan yang paling menakutkan adalah tindakan pemerkosaan terhadap anak. Promosi kesehatan sebagai langkah preventif terhadap permasalahan kekerasan seksual ini perlu diupayakan dan diperlukan bagi anak (Barron \& 
Topping, 2009). Upaya promosi sebagai prevensi kekerasan seksual pada anak sebaiknya diperkenalkan dan diajarkan sejak primer. Salah satu tempat untuk melakukan promosi kesehatan tentang kekerasan seksual ini adalah sekolah. Sebagian waktu dari anak-anak dihabiskan dengan kegiatan belajar atau kegiatan lain yang berlokasi di sekolah tempat dimana mereka lepas dari pengawasan orangtua atau keluarga. Artinya anak harus mampu menjaga dirinya baik di sekolah maupun tempat di luar lingkungan sekolah (Skarbek, Hahn \& Parrish, 2009).

Menurut Skarbek, Hahn \& Parrish (2009) melalui peran guru di sekolah, siswa belajar menyadari keberadaan individu lain di luar diri dan keluarganya. Guru merupakan agen pengubah serta menjadi mediator yang tepat untuk menyampaikan informasi kepada para siswanya, baik informasi yang berkaitan dengan kurikulum pendidikan di sekolah maupun non kurikulum misalnya informasi tentang kesehatan, kesehatan seksual, kekerasan seksual dan perlindungan terhadap anak (Paramastri, 2010).

Berbicara tentang prevensi primer artinya pencegahan dilakukan sejak dini, maka tatanan SD merupakan pilihan yang tepat untuk melakukan prevensi terkait kekerasan seksual pada anak. Hal ini diperkuat oleh Goldman \& Grimbeek (2011) bahwa usia SD banyak dinilai pemerhati anak merupakan waktu yang tepat untuk memberikan pemahaman mengenai kekerasan seksual secara lebih jelas. Pengetahuan, sikap dan keterampilan seorang guru sangatlah penting dalam melakukan prevensi kekerasan seksual pada anak. Oleh sebab itu peneliti tertarik untuk melakukan penelitian tentang pengetahuan, sikap dan keterampilan guru dalam menyampaikan prevensi dini kekerasan seksual pada anak dengan menggunakan "Pelatihan pada Guru". Pelatihan ini merupakan program yang disusun oleh peneliti untuk melaksanakan pelatihan terhadap guru. Program ini bertujuan meningkatkan pengetahuan, sikap dan keterampilan guru tentang prevensi primer kekerasan seksual pada anak. Para guru diharapkan dapat dengan mudah menerapkan dan menyampaikan pada siswa SD. 
Berdasarkan uraian dari latar belakang masalah di atas maka rumusan masalah yang diajukan adalah: "Apakah pelatihan perlindungan anak pada guru SD sebagai prevensi primer terhadap kekerasan seksual pada anak (KSA) dapat meningkatkan pengetahuan, sikap dan keterampilan menyampaikan informasi kepada siswa di Tulungagung Jawa Timur?"

Tujuan penelitian ini adalah menguji pemberian "pelatihan perlindungan anak pada Guru SD" untuk peningkatan pengetahuan, sikap dan keterampilan menyampaikan informasi sebagai prevensi primer kekerasan seksual pada anak SD di Tulungagung Jawa Timur.

\section{Metode Penelitian}

Variabel bebas (independent variable): Pelatihan perlindungan anak pada Guru. Variabel terikat (dependent variabel): a. pengetahuan tentang KSA pada guru SD, b. sikap guru SD tentang KSA, c. keterampilan guru SD menyampaikan informasi terhadap pevensi primer KSA.

Program pelatihan terhadap guru adalah bentuk intervensi melalui serangkaian proses belajar dengan menggunakan modul sebagai medianya. Isi dari modul diantaranya definisi KSA, jenis KSA, dampak KSA, area yang rentan terhaadap KSA, strategi prevensi KSA. Pengetahuan guru SD adalah pemahaman guru tentang KSA dan prevensinya. Penilaian menggunakan kuesioner dengan pilihan jawaban benar dan salah dilakukan sebelum dan setelah program. Pernyataan benar diberi nilai 1 dan salah diberi nilai Odikatagorikan dengan skala ordinal : Kurang (< 56), Cukup (56-75) dan Baik (>75). Sikap guru adalah adalah reaksi atau tanggapan responden tentang KSA yang diukur menggunakan kuesioner tertutup dengan skala likert yaitu menggunakan lima pilihan jawaban mulai dari sangat tidak setuju diberi nilail samapi sangat setuju diberi nilai 5 dikatagorikan dengan skala ordinal : Kurang ( $<56)$, Cukup (56-75) dan Baik (>75). Keterampilan guru adalah kemampuan guru dalam menyampaikan pesan kepada siswa tentang KSA dan pencegahannya. Pengukuran menggunakan skala likert yaitu menggunakan lima pilihan jawaban mulai 
dari sangat kurang baik diberi nilai 1 sampai sangat baik diberi nilai 5dikatagorikan dengan skala ordinal : Kurang $(<56)$, Cukup (56-75) dan Baik (>75).

Pemilihan subjek sebagai sampel dilakukan dengan teknik purposive sampling, dengan kriteria inklusi dan eksklusi. Subjek penelitian adalah para guru di SDN I, II Kenayan dan SDN III, IV Kepatihan di kecamatan Tulungagung.Subjek terdiri atas 10 guru sebagai kelompok eksperimen dan 11 guru sebagai kelompok kontrol. Pengambilan subjek kelompok kontrol diupayakan mempunyai karakteristik demografis yang sama dengan kelompok perlakuan agar pengaruh karakteristik responden dapat dikendalikan (Murti, 2006). Kriteria inklusi: a. Bersedia menjadi responden, b. Sehat jasmani dan rohani, c. Guru wali kelas, d. Bukan tenaga honorer, e. Masa bertugas minimal 5 tahun.

Pengukuran pengetahuan guru menggunakan kuesioner tertutup, dengan 2 pilihan jawaban benar dan salah (Azwar, 2007). Pertanyaan meliputi definisi KSA, jenis KSA, dampak $\mathrm{KSA}$, area yang rentan terhaadap KSA, strategi prevensi KSA. Pengukuran sikap guru menggunakan kuesioner tertutup, berdasarkan skala Likert dengan 5 pilihan jawaban sangat tidak setuju sampai sangat setuju (Azwar, 2013). Pengukuran keterampilan guru menggunakan checklist yang diisi oleh observer, dilakukan sebelum program dan setelah program (Hadi, 2004). Keterampilan guru dalam prevensi KSA meliputi keterampilan komunikasi verbal dan non verbal. Lembar observasi yang dimodifikasi dari Wijayanti (2013) yang berdasarkan aspek-aspek keterampilan menyampaikan infoormasi baik secara verbal maupun non-verbal versi Brown dan Monogue (2001).

Uji coba dilakukan untuk menguji validitas dan reliabilitas alat ukur. Uji coba dilakukan pada bulan September 2014 dengan melibatkan 15 responden. Seleksi item dilakukan dengan mengkorelasikan tiap butir dengan skor totalnya. Batasan yang digunakan adalah $\geq 0,3$ (Azwar, 2013). 
Setelah uji coba item dilakukan, diperoleh koefisien reliabilitas sebesar 0,959 dengan korelasi item skor berada pada kisaran 0,564 sampai 0,908. Dilakukan seleksi item sehingga korelasi aitem skor berada kisaran 0,571 sampai 0,904 dengan koefisien reliabilitas sebesar 0,985.

Penelitian ini mengunakan kuasi eksperimen. Desain eksperimen yang akan digunakan dalam penelitian ini adalah untreated control group design with pre-test and post-test (Shadish, Cook \& Campbell, 2002).

Perlakuan yang diberikan berupa pelatihan perlindungan anak oleh guru terhadap kekerasan seksual anak (KSA) yang terdiri dari 3 bagian, yaitu 1) memberikan pengetahuan terhadap guru mengenai kekerasan seksual pada anak (KSA), 2) memberikan perubahan sikap guru terhadap kekerasan seksual pada anak (KSA), 3) memberikan keterampilan menyampaikan informasi secara verbal dan non-verbal pada guru.

Modul pada penelitian ini mengadaptasi dan memodifikasi materi dalam buku KDRT dan Pelecehan Seksual dalam kehidupan anak usia primer yang disusun oleh Lazzarini (2011) dari Direktorat Pembinaan Pendidikan Anak Usia Primer, media kampanye pencegahan kekerasan seksual pada anak "Stop It Now", keterampilan menyampaikan informasi dimodifikasi dari Wijayanti (2013) yang berdasarkan aspekaspek keterampilan menyampaikan informasi baik secara verbal maupun non-verbal versi Brown dan Monogue (2001). Sebelum digunakan dalam pelatihan, modul tersebut diujicobakan untuk mengetahui validitas. Modul divalidasi dengan pendekatan validitas isi, yaitu validitas yang diestimasi melalui pengujian terhadap isi tes dengan analisis rasional dan penilaian (professional judgement) dari individu yang dianggap ahli di bidangnya (Supratiknya, 2011). Validasi modul dilakukan oleh LSM Rifka Anisa pada program KSA di Yogyakarta. Dalam penelitian ini, para ahli yang dimintai penilaiannya adalah dosen yang memiliki pengalaman di bidang kekerasan seksual pada anak (KSA), trainer di sebuah LSM yang bergerak di bidang kekerasan seksual pada anak (KSA), dan trainer di sebuah LPA di Tulungagung. 
Perlakuan dalam bentuk pelatihan dilakukan selama 3 hari yang terdiri 2 sesi. Pelatihan dilaksanakan di ruang aula di sekolah. Susunan kursi pada saat pelatihan disusun berdasarkan kelompok sehingga suasana pelatihan berlangsung dekat satu sama lain. Metode yang digunakan dalam proses pelatihan adalah diskusi (andragogi) yaitu pembelajaran pada orang dewasa sehingga tidak membosankan dan role play. Media yang digunakan dalam pelatihan adalah tayangan berupa kasus-kasus, power point, dan lembar-lembar kerja. Lembar-lembar kerja yang disampaikan oleh fasilitator dikemas dalam bentuk permainan, tanya jawab dan diskusi. Pelatihan ini dipandu oleh fasilitator yang diamati oleh observer dengan kualifikasi sebagai berikut: (1) Fasilitator adalah konselor kekerasan seksual pada anak dengan pengalaman lebih dari lima tahun, bekerja pada layanan public, dan berpengalaman dalam memberikan pelatihan kekerasan seksual pada anak; dan (2) Observer adalah mahasiswa S2 Psikologi.

Data yang diperoleh dalam penelitian dianalisis menggunakan uji Mann Whitney U-Test, untuk menguji perbedaan gain score kelompok eksperimen dan kelompok kontrol.

\section{Hasil Penelitian}

\section{PengujianMann Whitney}

Pengujian ini digunakan untuk mengetahui apakah secara statistika terdapat perbedaan pengetahuan, sikap dan keterampilan pada kedua kelompok (kontrol dan eksperimen). Tabel 1 berikut ini merupakan hasil uji perbedaan tersebut.

\section{Tabel 1 Ringkasan Hasil Uji Mann Whitney Test, Perbedaan Pengetahuan, Sikap dan Perilaku Kelompok Kontrol dan Eksperimen Setelah Diberikan Program Pelatihan}

\begin{tabular}{lllll}
\hline Hasil Uji & Pengetahuan & Sikap & Keterampilan \\
\hline Pre & Z hitung & $-0,069$ & $-0,103$ & $-0,381$ \\
& P value & 0,945 & 0,918 & 0,703 \\
\hline Post & Z hitung & $-2,393$ & $-2,697$ & $-2,132$ \\
& P value & 0,017 & 0,007 & 0,033 \\
\hline
\end{tabular}


Berdasarkan tabel 1 tersebut diketahui nilai $\mathbf{Z}$ hitung dari hasil pengujian setelah diberikan program latihan (post) menunjukkan baik pada pengetahuan, sikap dan keterampilan didapatkan angka $p$ value di bawah $0,05(p<0,05)$ dengan Gain skor sebesar 4,4. Hal ini berarti ada perbedaan signifikan pengetahuan, sikap dan keterampilan pada guru tentang KSA. Dengan kata lain adanya program latihan yang diberikan kepada kelompok eksperimen berpengaruh terhadap peningkatan pengetahuan, sikap dan keterampilan guru tentang KSA.

\section{Uji Gain Score}

Tabel 2 Ringkasan Hasil Uji Gain Score dan Sumbangan Efektif pada Kelompok Eksperimen

\begin{tabular}{lllll}
\hline Hasil Uji & & Pengetahuan & Sikap & Keterampilan \\
\hline Gain & Z hitung & $-3,502$ & $-3,151$ & $-2,543$ \\
Score & P value & 0,000 & 0,002 & 0,011 \\
\hline
\end{tabular}

Berdasarkan Tabel 2 tersebut diketahui nilai $Z$ hitung dari hasil pengujian setelah dilakukan perhitungan gain score didapatkan angka $p$ value di bawah 0,05 ( $p<0,05$ ). Hal ini berarti ada perbedaan signifikan gain score pengetahuan, sikap dan keterampilan pada guru tentang KSA.

\section{Pembahasan}

\section{Pengetahuan}

Peningkatan pengetahuan merupakan salah satu tujuan yang ingin dicapai dalam pendidikan kesehatan. Menurut Barron dan Topping (2009)selain peningkatan pengetahuan (knowledge), tujuan lainnya adalah perubahan sikap (attitude), dan keterampilan dan tingkah laku (practice). Pengetahuan termasuk di dalam area kogntif karena di dalamnya ada fakta dan konsep. Pengetahuan seseorang terhadap suatu objek dapat berubah dan berkembang sesuai dengan kemampuannya, kebutuhannya, pengalaman dan tinggi rendahnya mobilitas materi informasi tentang objek tersebut. Individu memperoleh pengetahuan berdasarkan pengalaman belajar yang terstruktur dan pengalaman hidup setiap hari. Perubahan positif pada pengetahuan akan menjadi 
perantara, motivasi dan niat untuk perubahan perilaku atau membuat perilaku mudah untuk berubah (Walsh\& Brandon, 2012). Informasi yang diperoleh baik dari pendidikan formal maupun non formal dapat memberikan pengaruh jangka pendek (immediate impact) sehingga menghasilkan perubahan atau peningkatan pengetahuan. Majunya teknologi akan tersedia bermacam-macam media massa yang dapat mempengaruhi pengetahuan masyarakat tentang inovasi baru. Sebagai sarana komunikasi, berbagai bentuk media massa seperti televisi, radio, surat kabar, majalah, dan lain-lain mempunyai pengaruh besar terhadap pembentukan opini dan kepercayan orang. Dalam penyampaian informasi sebagai tugas pokoknya, media massa membawa pula pesan-pesan yang berisi sugesti yang dapat mengarahkan opini seseorang. Adanya informasi baru mengenai sesuatu hal memberikan landasan kognitif baru bagi terbentuknya pengetahuan terhadap hal tersebut (Notoatmodjo, 2010). Program pelatihan tentang KSA pada dasanya merupakan salah satu upaya untuk memberikan perlindungan pada anak.

\section{Sikap}

Sikap merupakan evaluasi dan reaksi perasaan seseorang terhadap suatu objek dengan perasaan mendukung atau memihak (favourable) dan perasaan tidak mendukung atau tidak memihak (unfavourable) terhadap objek (Azwar, 2013). Sikap belum merupakan tindakan atau perilaku, dan sikap tidaklah sama dengan perilaku, begitu juga sebaliknya perilaku tidaklah selalu mencerminkan sikap seseorang, sebab seringkali terjadi bahwa seseorang memperlihatkan tindakan yang bertentangan dengan sikapnya. Sikap seseorang dapat berubah dengan diperolehnya tambahan informasi tentang objek tertentu, melalui persuasi serta tekanan kelompok sosial (Sarwono, 2002).

Sikap yang dimiliki tiap responden seperti telah disebutkan di atas, disebabkan karena faktor kepribadian, intelegensi serta minat dari tiap responden yang berbedabeda. Intelegensi dalam hal ini juga berhubungan dengan kemampuan dari tiap-tiap individu untuk menyerap informasi yang mereka dapatkan yang nantinya akan berpengaruh pada 
tingkat pengetahuan mereka. Dimana kemudian dengan pengetahuan yang mereka miliki sebelumnya, nantinya juga akan dapat mempengaruhi terbentuknya sikap seseorang terhadap suatu hal, yang dalam hal ini adalah sikap guru tentang KSA. Hal ini sesuai dengan Azwar (2013), yang menyatakan bahwa sikap belum otomatis terwujud dalam suatu tindakan. Untuk terwujudnya sikap menjadi suatu perbuatan nyata diperlukan faktor pendukung atau suatu kondisi yang memungkinkan, antara lain fasilitas. Disamping itu perlu adanya dukungan dari berbagai pihak, misalnya petugas penyuluh, suami, orang tua, teman, dan lain sebagainya termasuk adanya program pelatihan.

\section{Keterampilan}

Berdasarkan hasil tersebut, mengindikasikan bahwa terjadi perubahan yang lebih baik dari kelompok eksperimen dengan adanya program pelatihan. Prevensi primer yang dilakukan pada penelitian ini menggunakan psikoedukasi pelatihan. Menurut Nelson-Jones psikoedukasi merupakan suatu usaha yang membantu mengembangkan aneka life skills atauketerampilan hidup melalui aneka program terstruktur yang diselenggarakan berbasis kelompok. Beberapa life skills meliputi, kemampuan memahami orang lain secara empatik, kemampuan menyelesaikan masalah dan membuat perencanaan, dan kemampuan menjalani aneka transisi kehidupan secaraefektif. Pelatihan adalah suatu kegiatan yang bermasud untuk memperbaiki dan mengembangkan sikap, perilaku, keterampilan dan pengetahuan seseorang sesuai dengan tujuan tertentu (Nitisemito, 1994).

Pengaruh program perlindungan anak oleh Guru SD terhadap KSA terhadap peningkatan Pengetahuan, Sikap, dan Keterampilan menyampaiakn informasi sebagai prevensi primer kekerasan seksual pada anak (KSA).

Di Indonesia, sudah ada UU No.23 tahun 2002, tentang Perlindungan Anak, tapi pada prakteknya hukuman yang dijatuhkan pada pelaku masih mengacu pada KUHP, yang notabene lebih ringan. Mirisnya, para pelaku sulit untuk dideteksi. Para pelaku ini, umumnya adalah orang yang bisa cepat akrab dan sayang terhadap anak-anak. la juga pandai 
membujuk. Mungkin, karena para pelaku bisa bersikap sangat sopan dan halus tutur katanya. Diagnosa pelecehan seksuan ini sering menjadi sangat kompleks. Bukti fisik yang meyakinkan pada pelecehan seksual relatif sulit ditemukan dalam kasus-kasus yang dicurigai. Untuk semua alasan ini, bila diduga telah terjadi pelecehan, harus segera dikonsultasikan dengan seorang profesional kesehatan yang terlatih (Soekresno, 2007). Temuan dari hasil penelitian mengindikasikan bahwa terjadi perubahan peningkatan pengetahuan, sikap dan keterampilan guru SD setelah diberikannya program pelatihan. Dengan kata lain bahwa setelah orang belajar dan atau mendapatkan program pelatihan, pengetahuan, sikap dan keterampilan orang tersebut akan mengalami perubahan ke arah yang lebih baik. Pembelajaran dengan modul (Brown, Reingold, Campbell \& Areliano, 2008) adalah suatu proses belajar mengenai satuan bahasan tertentu yang disusun secara sistematis, operasional dan terarah untuk digunakan oleh peserta disertai pedoman penggunaannya.

Pengetahuan dan keterampilan mempunyai hubungan yang erat, keterampilan merupakan aplikasi dari pengetahuan yang diperoleh (Ogunfowokan\& Fajemilehin, 2012). Menurut Sarwono (1997), keterampilan adalah rangsangan yang bersumber pada kemampuan seseorang untuk mengadopsi dan melanjutkan perilaku yang baru. Keterampilan dapat terwujud melalui langkah-langkah yaitu: instruksi, demonstrasi, simulasi, melalui umpan balik, serta penguatan. Keterampilan akan tercapai dengan melakukan penugasan atau mempraktikkannya ke dalam situasi nyata (Bartholomew, Parcel, Kok \& Gottlieb, 2006).

Dalam konteks penelitian ini pemberian informasi program pelatihan merupakan suatu usaha untuk mengembangkan kepribadian dan kemampuan. Semakin banyak informasi yang masuk semakin banyak pula pengetahuan yang didapat tentang kesehatan. Pengetahuan seseorang tentang sesuatu objek juga mengandung dua aspek yaitu aspek positif dan negatif. Kedua aspek inilah yang akhirnya akan menentukan sikap seseorang terhadap objek tertentu. Semakin banyak aspek positif dari objek yang 
diketahui, akan menumbuhkan sikap makin positif terhadap objek tersebut (Goldman \& Grimbeek, 2011).

Program pelatihan merupakan proses perubahan, yang bertujuan untuk mengubah individu, kelompok dan masyarakat menuju hal-hal yang positif secara terencana melalui proses belajar. Perubahan tersebut mencakup antara lain pengetahuan, sikap dan keterampilan melalui melalui proses program pelatihan (Machfoed, 2005). Tujuan utama program pelatihan adalah agar orang mampu menerapkan masalah dan kebutuhan mereka sendiri, mampu memahami apa yang dapat mereka lakukan terhadap masalahnya, dengan sumber daya yang ada pada mereka ditambah dengan dukungan dari luar, dan mampu memutuskan kegiatan yang tepat guna untuk meningkatkan taraf hidup sehat dan kesejahteraan masyarakat (Mubarak, 2009).

Berkaitan dengan hasil penelitian ini, maka dengan program pelatihan dapat menimbulkan dampak pengaruh yang baik terhadap perubahan pengetahuan, sikap dan keterampilan guru SD di Kabupaten Tulungagung. Pemberian program pelatihan (Edelman \& Mandle, 2006) merupakan salah satu bentuk kegiatan penyampaian informasi kesehatan yang dilakukan dengan menyebarkan pesan, menanamkan keyakinan, sehingga masyarakat tidak hanya sadar, tahu dan mengerti, tetapi juga mau dan bisa melakukan suatu anjuran yang ada hubungannya dengan kesehatan. Menjadikan kesehatan menurut Golish (2000) sebagai sesuatu yang bernilai dimasyarakat, menolong individu agar mampu secara mandiri atau kelompok mengadakan kegiatan untuk mencapai tujuan hidup sehat, mendorong pengembangan dan menggunakan secara tepat sarana pelayanan kesehatan yang ada secara tepat.

Peran guru dalam dunia pendidikan modern sekarang ini semakin kompleks, tidak sekedar sebagai pengajar semata, pendidik akademis tetapi juga merupakan pendidik karakter, moral dan budaya bagi siswanya. Guru haruslah menjadi teladan, seorang model sekaligus mentor dari anak/ siswa di dalam mewujudkan perilaku yang berkarakter yang meliputi olah pikir, olah hati dan olah rasa (Kenny, Bennett, Dougery, Steela, 2013).Anak-anak menurut Maclntyre dan Carr (2000) 
merupakan kelompok yang sangat rawan terhadap tindakan kekerasan, seperti penganiayaan, pelecehan bahkan yang paling menakutkan adalah tindakan pemerkosaan terhadap anak.Promosi kesehatan sebagai langkah preventif terhadap permasalahan kekerasan seksual ini perlu diupayakan dan diperlukan bagi anak.Anak-anak perlu mendapat sosialisasi dan diarahkan untuk membekali diri dengan meningkatkan kewaspadaan, menambah pengetahuan dan pemahamannya agar lebih peka terhadap berbagai tanda yang mengarah pada percobaan atau ajakan yang berkonotasi seksual (Barron \& Topping, 2009).

Dengan adanya Undang-Undang Nomor 23 tahun 2002 tentang Perlindungan Anak merupakan alat hukum yang mampu untuk melindungi anak dalam berbagai tindak pidana khususnya kekerasan seksual terhadap anak. Undang-Undang tersebut menyatakan bahwa kekerasan seksual terhadap anak merupakan tindak pidana sehingga pelaku dapat diajukan ke kepolisian atas pendampingan pihak terkait.

Ditinjau dari Undang-Undang Nomor 23 tahun 2002 tentang Perlindungan anak Pasal 3 dinyatakan bahwa, perlindungan anak adalah segala kegiatan untuk menjamin hak-hak anak agar dapat hidup, tumbuh, berkembang dan berpartisipasi secara optimal sesuai dengan harkat dan martabat kemanusiaan, serta mendapat perlindungan dari kekerasan dan diskriminasi. Maksud perlindungan kekerasan terhadap anak di atas terhadap kasus kekerasan seksual anak diperjelas dalam Pasal 69 ayat 1 Undang-Undang Nomor 23 tahun 2002 tentang Perlindungan Anak yang meliputi kekerasan fisik, psikologis dan kekerasan seksual. Permasalahan kekerasan seksual terhadap anak di bawah umur dalam Undang-Undang Nomor 23 tahun 2002 tentang Perlindungan Anak Bab IX tentang Penyelenggaraan Perlindungan dan Bab XII tentang ketentuan pidana terhadap pelaku tindak kekerasan seksual terhadap anak di bawah umur.

Diantara implementasi perlindungan terhadap anak korban kekerasan seksual dalam Pasal Undang-Undang tentang Perlindungan Anak tersebut yaitu : Pertama, Pasal 59 Undang-Undang Nomor 23 tahun 2002 tentang Perlindungan 
Anak yang menyatakan perlindungan terhadap anak dalam situasi tereksploitasi secara ekonomi, seksual maupun anak yang diperdagangkan, pemerintah dan lembaga negara lain berkewajiban dan bertanggungjawab untuk memberikan perlindungan khusus. Kedua, Pasal 82 Undang-Undang Nomor 23 tahun 2002 tentang Perlindungan Anak yang dinyatakan bahwa setiap orang yang dengan sengaja melakukan kekerasan maupun dengan ancaman kekerasan, memaksa dengan tipu muslihat dan serangkaian kebohongan serta membujuk anak untuk melakukan perbuatan cabul dipidana dengan pidana maksimal 15 tahun dan serendahrendahnya 3 tahun kurungan penjara.

\section{Penutup}

\section{Kesimpulan}

Pelatihan perlindungan anak pada guru dapat meningkatkan pengetahuan, sikap dan keterampilan pada guru SD sebagai prevensi primer terhadap KSA. Pengetahuan, sikap dan keterampilan menyampaikan informasi pada kelompok eksperimen lebih tinggi dibanding kelompok kontrol. Dengan gain score 0,00 pada pengetahuan, 0,002 pada sikap, 0,001 pada keterampilan.

\section{Keterbatasan dan Saran}

1. Dalam penelitian ini hanya menggunakan satu guru satu observer karena keterbatasan jumlah observer dalam penelitian. Disarankan peneliti berikutnya menggunakan lebih dari satu observer pada satu guru.

2. Responden yang digunakan pada penelitian ini hanya pada lingkup guru. Disarankan peneliti berikutnya lebih memperhatikan sampai pada anak didik atau siswa.

3. Para guru SD di Tulung Agung agar terus menggali informasi, menambah wawasan dan pengetahuan untuk mengantisipasi atau mencegah kekerasan seksual anak serta mengajarkan prevensi pada siswa terkait dengan kekerasan seksual anak (KSA).

\section{Daftar Pustaka}


Azwar, S. (2007).Penyusunan Skala Psikologi. Pustaka pelajar: Yogyakarta.

Azwar, S. (2013). Sikap Manusia, Teori dan Penyusunannya. Pustaka Pelajar: Yogyakarta.

Bandura, A. (1986).Sosial foundations of thought and action a sosial cognitive theory, Prentice-Hall. Englewood Cliffs.

Barron, lan, G., Topping, Keith, J. (2009). School-Based Child Sexual Abuse Prevention Programs.A Review of Effectiveness, 79 (1), 431-463. DOI: 10.3102/0034654308325583.

Barron, lan, G., \&Topping, Keith, J. (2010)b.Sexual Abuse Prevention Programme Fidelity: Video Analysis of Interactions. Child Abuse Review, 20: 134-151. DOI: 10.1002/car.1134.

Bartholomew, L. K; Parcel, G. S; Kok, G., \& Gottlieb, N. H. (2006). Planning health promotion programs: An intervention mapping approach. American Journal of Health Studies, second edition, Jossey- Bas, A Wiley Imprint.

Bloom, Martin. (1996). Primary Prevention Practices; Issues in children's and families' lives, volume 5, Sage Publications, Inc.

Brown, G., \& Monogue, M. (2001). AMEE medical education guide no 22: Refreshing lecturing: Guide for lecturer. Medical teacher, 23 (3), 231-244.

Brown, S. S; Rheingold, A.A; Campbell, C and Areliano, M. A. (2008).A media campaign prevention program for child sexual abuse. Journal of Interper, vol, 6, 728-242.

Edelman, C. L \& Mandle, C. L. (2006). Health promotion: Throughout the life span. J Fam Viol, Elsevier, Mosby, Inc.

Erogul, Ayse. R. C., \&Hasirci, Ozlem, K. (2013). The Effectiveness of psycho-educational school-based child sexual abuse prevention training program onturkish 
elementary students.Educational sciences: Theory \& practice,13 (2), 725-729.

Finkelhor, David. (2007). Prevention of sexual abuse Through educational programs directed toward children. Jour of Ped Psychol. 120. 640-645.

Goldman, Juliette, D. G. (2010). Australian undergraduate primaryschool student-teachers' responsesto child sexual abuse and its mandatory reporting. Pastoral care in education, 28(4),283-294. DOI: 10.1080/02643944.2010.530679.

Goldman, Juliette, D. G., \& Grimbeek, Peter (2011). Sources of knowledge of departmental policy on child sexualabuse and mandatory reporting identified by primary schoolstudent-teachers. Education review,63(1), 1-18. DOI: 10.1080/00131911003717220.

Golish, T. D. (2000). Changes in closeness between adult children and their parents: A Turingpoint analysis. Communication Reports, 13(2), 79-96.

Hadi. (2004). Program Mengajar Guru. Yusri Art: Surabaya.

Johnson, C. F. (2004). Child sexual abuse. The lancet, 363:462-270.

Kenny, Maureen, C., Bennett, Kyle, D., Dougery, Jonelle., Steele, Francesca. (2013). Teaching general safety and body safety training skills to a latino preschool male with Autism. J Fam Viol, 22: 1092-1102. DOI: 10.1007/s10826-012-9671-4.

Lazzarini, V. (2011). KDRT dan peleceehan seksual dalam kehidupan AUD. Jakarta: Kementrian pendidikan nasional.

Machfoed, A. (2005). Pelatihan guru hebat. Numed: Yogyakarta.

Maclntyre, Deirdre., \& Carr, Alan. (2000). Prevention of child sexual abuse: Implications of programme evaluation research. Review of education research, 9, 183-199. 
Mubarak, B. (2009). Tujuan seorang guru. Yusri Art: Surabaya.

Murphy, G. (2002). Beyond surviving safety program: Toward a movement to prevent child sexual abuse. MsFoundation for Women.

Murti, T. (2006).Statistika kesehatan. Numed: Yogyakarta.

Nitisemito, R. (1994). Pelatihan pada calon guru. Numed: Yogyakarta.

Notoatmodjo, S. (2010). Promosi kesehatan teori dan aplikasi. Jakarta: PT Rineka Cipta.

Ogunfowokan, Adesola, A., \& Fajemilehin, R.B. (2012). Impact of a School-Based Sexual AbusePrevention Education Program onthe Knowledge and Attitude ofHigh School Girls.The Journal of school Nursing, 28(6), 459-468. DOI: 10.1177/1059840512446949.

Paramastri, I. (2010). Modifikasi teori transteoritikal untuk komunitas anti kekerasan seksual pada anak-anak (kaksa). (Disertasi tidak diterbitkan). Fakultas Psikologi Universitas Gadjah Mada, Yogyakarta.

Rahimi, Regina.,\& Liston, Delores. (2011). Race, class, and emerging sexuality: Teacher perceptions and sexualharassment in schools. Gender and education, 23(7), 799-810. DOI: 10.1080/09540253.2010.536143.

Regnerus \& Luchier. (2006). Parent child relationship and opportunities for adolescent's first sexs. Journal of Family Issues, 27 (2), 159-183.

Samsudin, A. (2009). Pusat data dan informasi komnas perlindungan anak.Diakses pada 21 Desember 2013 dari www.kompas.com.

Sarwono. (1997). Menggali potensi sang guru. Pustaka Pelajar: Yogyakarta.

Sarwono, S. (2002). Psikologi remaja. Raja Grafindo Persada: Jakarta. 
Shadish, W. R., Cook, T. D., \& Campbell, D.T. (2002).Experimental and Quasi-Experimental Design for Generalized Causal Inference. Houghtoon Mifflin Company.

Skarbek, Denise., Hahn, Karen., Parrish, Patricia. (2009). Stop sexual abuse in special education: An ecological model of prevention and intervention strategies for sexual abuse in special education. Sexuality and disability, 27:155-164. DOI: 10.1007/s11195-009-9127-y.

Soekresno. (2007). Menggali dan mencegah terjadinya tindak kekerasan terhadap anak. Rineka Cipta: Jakarta.

Supratiknya, H. (2011). Psikoedukasi dan pengembangannya. Numed: Yogyakarta.

Walsh, Kerryam., \&Brandon, Leisa. (2012).Their Children's First Educators: Parents' Views About ChildSexual Abuse Prevention Education. Original paper, 21: 734-746. DOI: 10.1007/s10826-011-9526-4.

WHO. (1988). Pendidikan kesehatan. Tjitarsa, I. B. (1992). (Alih Bahasa). ITB: Bandung.

Wijayanti, S. (2013). Guru sebagai mediator sosialisasi kesehatan reproduksi pada siswa SLTP. Tesis. Tidak dipublikasikan. Program Magister Psikologi Profesi. Yoogyakarta: Universitas Gadjah Mada. 